\title{
Validity and Reliability Instrumen of Noble Character of Adolescence
}

\author{
Heny Narendrany Hidayati ${ }^{1}$, Bahrul Hayat ${ }^{2}$, Wardani Rahayu ${ }^{3}$ \\ \{Heny.fitk@yahoo.com ${ }^{1}$, bhayat59@yahoo.com ${ }^{2}$,wardani9164@yahoo.com $\left.{ }^{3}\right\}$ \\ 1,2,3 Universitas Negeri Jakarta, Jl. Rawamangun Muka, Rawamangun, Pulo Gadung, Kota \\ Jakarta Timur, Daerah Khusus Ibukota Jakarta 13220, Indonesia
}

\begin{abstract}
The instrument of noble character is arranged to get a valid and reliable instrument that can measure the noble character of students in Islamic Senior High School. The research method uses a survey, with the number of testing respondents as many as 597 students, using a Likert scale model. Instrument testing begins with a theoretical validity test by 4 experts and 20 panel members by examining the instrument items. Experts analyzes qualitatively, after the instrument is corrected as suggested by expert advice. Then it is examined by a panel that analyzes quantitatively using the Aiken index of 69 items, 17 indicators and 4 dimensions. The results of the analysis show that all items are valid. The next step is empirical validity test, where analysis of measurement model uses Confirmatory Analysis Factor (CFA) with Lisrel 8.80 Full Version program. The test results show 62 items valid, with criteria of SLF value $\geq 0.30$ and $\mathrm{t}$-value $\geq 1.96$, and calculating reliability with construct Reliability (CR), the calculated results are reliable with $C R>0.70$. From the observation of the model compatibility test towards the noble character instrument, it can be concluded that there is a match between the theoretical and empirical models.
\end{abstract}

Keywords: CFA, Instrument, Lisrel

\section{Introduction}

Tobias Krettenauer et.al mentions that parental care, educational background and friends in their environment influence the moral motivation of adolescent [1]. Similar to this, Laible, Eye and Carlo mention that parenting patterns can develop dimensions of conscience that are complex which can affect moral behavior or actual behavior of adolescents [2]. Adolescence stage is the peak of involvement in crime as well as being vulnerable to external influences and change[3] .

Caroline Koh, mentions that there are problems in moral education, which is proven that there are criminal acts in adolescents in modern society, both in school and outside of school [4]. These conditions are due to increased adolescent moral emotions, which also show the development of morality in adolescence [1] .

In various countries moral cultivation is instilled through education, such as in Singapore and America. In Indonesia as well, morals in concept and practice can't be separated from religious education. In Indonesia, it is precisely known as noble morality [5]. The results of research by Bobbert, Miltiadis Proios and Ioannis Proios state that religion can influence moral values and behavior.

In third world countries with an Arab cultural and educational system, there is less demand for moral measurement with Defining Issues Test (DIT2) [6] . Therefore, it is 
considered important to establish valid and reliable religious moral or noble moral measurement instruments in Indonesia. Measurements are focused on the noble character of Madrasah Aliyah students who are at the level of adolescence.

\section{Noble Character}

The word akhlak in Al-Munjid is a plural word which means "manners, temperament, behavior" [7]. "Anis and Maskawih mention morality is a character that is united in the soul, from which gives birth to various actions performed spontaneously without requiring thought or consideration" [8]. Al-Ghazali mentions that if good deeds according to religion were brought about from it, then it can be said as noble morals, but if bad deeds were brought about from it, then it can be said as bad morals [9]. As the results of the Decade study state that moral intentions are based on moral judgments that grow from cognitive-intuitive development, emotional settings and understanding of morals and the underlying rules are illustrated [10]. The results of Xing $\mathrm{Xu}$ and Keung $\mathrm{Ma}$ research mention in everyday morality, individuals use deontological thinking (intuitive) which emphasizes the obligation of individuals to obey universal moral rules, as a basis for determining moral behavior [11]. Moral character is characterized by a consistent nature that is shown by someone in behaving in accordance with moral principles and norms of society[12] .

The right limit of behavior is that we do not do something wrong, whereas moral prohibitions refer to violations that we must avoid [13]. And the stages of developing Kohlberg's model reasoning abilities are based on cognitive development by Jean Piaget [14], by dividing into the three lowest levels namely pre-conventional (childhood), conventional middle level (late childhood and early adolescence), and the highest postconventional (adolescence and so on) [15]. Pre-conventional stage explains that moral values are not internalized in individuals, controllers are gifts and personal interests and punishments, conventional levels of morality are internalized and size comes from outside or other people, such as parents or punishment. Postconventional Reasoning, the individual knows the existence of other moral choices as options, and decides according to his personal moral code[16]. Students of Aliyah Madrasah are at the stage of postconventional reasoning, so it can be synthesized that the noble character of students is the behavior of students in the form of good deeds which is an inner picture that is done spontaneously without thinking, research and consideration which includes noble character to God, to self itself, to fellow humans and to the environment based on Islamic law.

\section{Method}

To get a high-quality moral instrument, it is necessary to test its validity and reliability. The description of the dimensions and indicators of noble variables is shown in table 1 .

Validity and reliability testing are step that must be taken to obtain a high-quality moral instrument. The noble moral variable consists of 4 dimensions, 17 indicators and 69 items. Theoretical Validity Test is carried out by 4 experts and 20 panelists who analyze the items in terms of content, construction and language. After the items are improved according to the next expert's suggestion, and analyzed by the panelists using the Aiken index, the calculated results show 69 items of valid instruments.

Table 1. Instruments of Noble Character

\begin{tabular}{lll}
\hline No & \multicolumn{1}{c}{ Dimension } & Indicators \\
\hline 1 & Moral to God & Prayer, fasting, resignation \\
\hline
\end{tabular}




\begin{tabular}{lll}
\hline 2 & Moral to yourself & Halal and good food and beverages, modest person \\
3 & Morals to fellow humans & $\begin{array}{l}\text { Honest, patient, humble, trustworthy, consistent, } \\
\text { discipline, obedient to parents, obedient to teachers, } \\
\text { affectionate }\end{array}$ \\
4 & Morals to the environment & $\begin{array}{l}\text { Nurturing plants, loving animals, maintaining } \\
\text { cleanliness }\end{array}$ \\
\hline
\end{tabular}

Furthermore, empirical validation was carried out on the questionnaire instrument in the form of a Likert scale model, with a choice of answers namely: always, often, sometimes, rarely, and never. Guidance guidelines for positive items, always $=5$, often $=4$, sometimes $=$ 3 , rarely $=2$, and never $=1$. The opposite is for negative items, never $=1$, rarely $=2$, sometimes $=3$, often $=4$, always $=5$ [17].

Empirical validation was carried out for Aliyah Madrasah students aged 16-17 years old with a total of 850 students, 597 of whom returned and filled out questionnaires. Validity item test uses the analysis of Structural Equation Modeling (SEM). The measurement model analysis was carried out by using Confirmatory Factor Analysis (CFA) with the Lisrel 8.80 Full Version program. If the Standard Loading Factor (SLF) analysis value is smaller than the critical limit $<0.70$ or 0.50 , then the observed variable should be removed from the model [18]. Besides the two critical boundary options, it is also explained that if the value of the standard factor load is $<0,50$ but $\geq 0.30$ and t-values $\geq 1.96$ or $\geq 2$, the observed variables can be considered not to be removed from the model, as also stated by Joseph F.Hair Jr.,William C. Black $\mathbf{J}$ and Babin Rolph E. standard instructors are valid in CFA for loading factor $\geq 0.30$ with the number of respondents $\geq 350$ [19]. Next is the testing technique to calculate reliability by using Construct Reliability (CR), with the Construct Reliability (CR) standard>0.70[20].

\section{Theoretical Validity}

Theoretical validation of the experts to the students' noble character instruments recommend that 11 items have to use the standard Indonesian language, 5 items have to be placed at the beginning of the sentence, 4 items must be more specific in measuring behavioral indicators and specific item is suggested to describe the student environment.

The results of the theoretical validation by panelists quantitatively show that 69 items of noble moral instruments have compatibility among dimensions, indicators, and statement items and are conceptually valid. Panelists conduct validation by using the Aiken index, the calculated results show that all items of mental health instruments were valid, with high calculation of the calculation results (0.61-0.80) and very high (0.81-1.00)

\subsection{Empirical Validity}

The item validity test was carried out by using Structural Equation Modeling (SEM) analysis, with the measurement model using Confirmatory Factor Analysis (CFA) with the Lisrel 8.80 Full Version program. Criteria of the item is said to be valid if the value of the Standard Loading Factor (SLF) is 0.30 with t-value $\geq 1.96$ or $\geq 2.00$.

The test results of the noble moral instrument containing 69 questions show that there were 62 valid items, and 7 items were invalid, then they are counted again and the calculated results show a fixed result of 62 items valid and 0 items invalid. The results of the analysis show that invalid items do not damage the indicator, which means that the valid items remain representative in representing the indicator. 


\subsection{Reliability}

The noble moral instrument reliability testing technique uses SEM analysis, namely evaluation of measurement reliability by using Construct Reliability (CR) by calculating reliability so that the level of consistency of manifest variables in measuring latent constructs can be seen. The results of the Construct Reliability (CR) calculation are as follows:

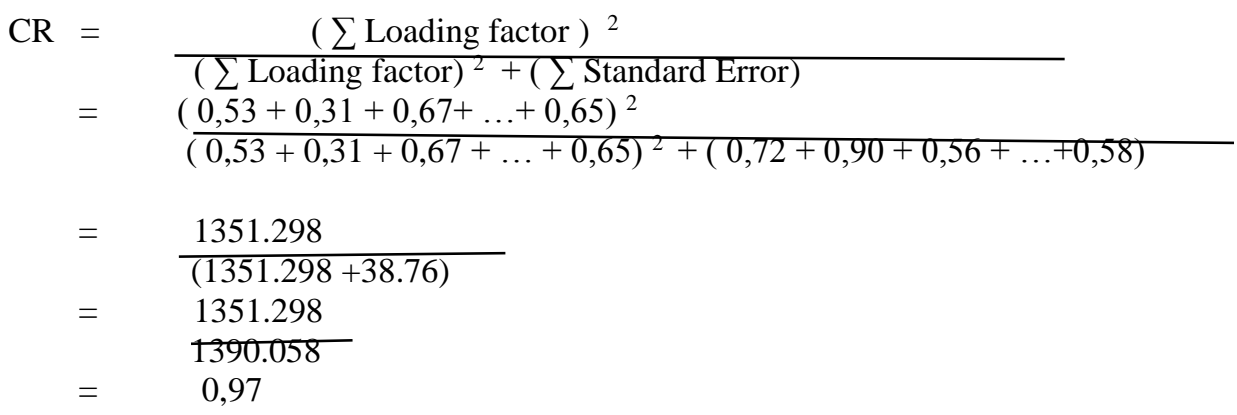

Acceptance standard of reliability, construct reliability $(\mathrm{CR})>0.70$. The calculation results show that the noble moral instrument is reliable, with Construct Reliability $(\mathrm{CR})=0.97$.

\section{Compatibility Test of the Entire Model}

The model compatibility test is used when there is a match between the theoretical model and the empirical model. Based on the ideal Goodness of Fit (GOF) criteria on noble moral instruments, it can be presented in the following table:

Table 2. Goodness of Fit Model

\begin{tabular}{|c|c|c|c|c|}
\hline $\mathrm{NO}$ & Feasibility Size & Value Criteria & Estimated Results & Conclusion \\
\hline 1 & $\begin{array}{l}\text { Chi square } \\
\mathrm{P}\end{array}$ & P Value $\geq 0.05$ & $\mathrm{P}$ Value $=0$ & Not Good \\
\hline 2 & $\begin{array}{l}\text { Root mean square error of } \\
\text { approximation } \\
\text { (RMSEA ) }\end{array}$ & $\leq 0.08$ & 0,061 & Good \\
\hline 3 & $\begin{array}{l}\text { Expected Cross Validation } \\
\text { Index } \\
\text { ( ECVI) }\end{array}$ & $\begin{array}{l}\text { ECVI Model < ECVI } \\
\text { Satured and Independence } \\
\text { model }\end{array}$ & $\begin{array}{l}M=9,94 \\
S=6,55 \\
I=80,47\end{array}$ & Fairly Good \\
\hline 4 & $\begin{array}{l}\text { Anti-image correlation } \\
\text { (AIC) }\end{array}$ & $\begin{array}{l}\text { AIC Model < AIC } \\
\text { Satured and } \\
\text { Independence Model }\end{array}$ & $\begin{array}{l}M=5925,02 \\
S=3906 \\
I=48295,30\end{array}$ & Fairly Good \\
\hline 5 & $\begin{array}{l}\text { Consistent Akaike } \\
\text { Information Index (CAIC) }\end{array}$ & $\begin{array}{l}\text { CAIC Model < CAID } \\
\text { Satured and Independence } \\
\text { Model }\end{array}$ & $\begin{array}{l}M=7326,92 \\
S=14436,41 \\
I=48295,30\end{array}$ & Good \\
\hline 6 & $\begin{array}{l}\text { Non-normed fit index } \\
\text { (NNFI) }\end{array}$ & $\geq 0.90$ & 0.94 & Good \\
\hline 7 & Normed fit index (NFI) & $\geq 0.90$ & 0.91 & Good \\
\hline 8 & $\begin{array}{l}\text { Parsimonious normed fit } \\
\text { index (PNFI) }\end{array}$ & $\geq 0.90$ & 0,82 & Fairly Good \\
\hline 9 & Comparative fit index (CFI) & $\geq 0.90$ & 0.94 & Good \\
\hline 10 & Incremental fit index (IFI) & $\geq 0.90$ & 0.94 & Good \\
\hline
\end{tabular}




\begin{tabular}{lllll}
\hline NO & Feasibility Size & Value Criteria & Estimated Results & Conclusion \\
\hline 11 & Relatif fit index (RFI) & $\geq 0.90$ & 0.90 & Good \\
12 & $\begin{array}{l}\text { Goodness of fit index ( GFI } \\
\text { ) }\end{array}$ & 00.90 & Fairly Good \\
13 & $\begin{array}{l}\text { Root mean square Residual } \\
\text { (RMR) }\end{array}$ & $\leq 0.08$ & 0.04 & Good \\
14 & $\begin{array}{l}\text { Adjusted goodness of fit } \\
\text { index (AGFI) }\end{array}$ & $\geq 0.90$ & 0.74 & Not Good \\
15 & $\begin{array}{l}\text { Parsimonious Goodness of } \\
\text { Fit Index (PGFI) }\end{array}$ & $\geq 0.60$ & 0.67 & Good \\
\hline
\end{tabular}

Based on the table above about the model compatibility test, it can be seen that there are three goodness of fit (GOF) sizes that show poor match, three GOF sizes that show fairly good match, and nine GOF sizes show good match. From the results of the model compatibility test it can be concluded that the compatibility of the model of the noble character as a whole is good, it can be proven that there are 9 measures of Goodness of Fit (GOF) showing the compatibility of the good model.

\section{Conclusion}

In the instrument of noble character, the process of theoretical validation and empirical validation is carried out. Theoretical validation is namely through experts and panels that examine items in terms of construction, content and language. The results of a study of 4 experts qualitatively stated that they were good, and there was only a little advice from experts on a small number of noble moral instruments to be referenced in terms of construction, content and language, so that in principle there were no significant changes after the items were corrected according to expert advice. The theoretical validation by 20 panels is carried out quantitatively by using the Aiken index, the calculated results show that all items of the instrument are valid, with the interpretation of the calculated results, which are high $(0.61$ $0.80)$ and very high(0,81-1.00).

The next step is empirical validation or testing of instruments into the field, testing the validity of the items empirically using Structural Equation Modeling (SEM) analysis. The measurement model analysis was carried out by using the Confirmatory Analysis Factor (CFA) 1 with the Lisrel 8.80 Full Version program.

The trial was conducted on 597 students, and the results show that from 69 items there were 62 valid items with criteria having SLF value $\geq 0.30$ and $t$-value $\geq 1.96$ or 2 , which means there were 7 invalid items. Then the noble moral instruments containing 62 valid items, calculated reliability with construct Reliability (CR). It show that it is reliable, with Construct Reliability $(\mathrm{CR})=0.97$. The next step is the model compatibility test that shows the model compatibility of the overall noble character instrument, both of which can be proven by the existence of 9 measures of Goodness of Fit (GOF) showing the compatibility of the good model.

\section{Reference}

[1] T. Krettenauer, T. Colasante, M. Buchmann, and T. Malti, “The Development of Moral Emotions and Decision-Making From Adolescence to Early Adulthood: A 6-Year Longitudinal Study," J. Youth Adolesc., vol. 43, no. 4, pp. 583-596, 2014.

[2] D. Laible, J. Eye, and G. Carlo, "Dimensions of conscience in mid-adolescence: Links with social behavior, parenting, and temperament," J. Youth Adolesc., vol. 37, no. 7, 
pp. 875-887, 2008.

[3] D. Schepers, "Moral development in adolescence: A test of change and influences in context of sat with German panel data," Contemp. Readings Law Soc. Justice, vol. 9, no. 1, pp. 70-97, 2017.

[4] C. Koh, "Moral development and student motivation in moral education: A Singapore study," Aust. J. Educ., vol. 56, no. 1, pp. 83-101, 2012.

[5] M. Saerozi, "Historical Study on the Changes of Religious and Moral Education in Indonesia," J. Indones. Islam, vol. 8, no. 1, p. 39, 2014.

[6] J. D. Rose, "Development of Moral Reasoning at a Higher Education Institution in Nigeria," Emerg. Leadersh. Journeys, vol. 5, no. 1, pp. 81-101, 2012.

[7] L. Ma'luf, "Al-Munjid," in Al-Maktabahas Syaroqiyah, Beirut: Al-Maktabahas Syaroqiyah, 2000, p. 194.

[8] I. Maskawih, "Tahzib Al-Akhlak wa Tathir Al-Agrok," in Tahzib Al-Akhlak wa Tathir Al-Agrok, Kairo: Al-Mathba'ah Al-Mishriyah, 1934, p. 40.

[9] A. Gazali, "Ihya Ulum Al-Din," Beirut: Dar Al-Fikri, 1991, p. 52.

[10] A. Dedeke, "A Cognitive-Intuitionist Model of Moral Judgment," J. Bus. Ethics, vol. 126, no. 3, pp. 437-457, 2013.

[11] Z. X. Xu and H. K. Ma, "How Can a Deontological Decision Lead to Moral Behavior? The Moderating Role of Moral Identity," J. Bus. Ethics, vol. 137, no. 3, pp. 537-549, 2016.

[12] H. Liu, X. Chen, and B. Zhang, "An approach for the accurate measurement of social morality levels," PLoS One, vol. 8, no. 11, pp. 1-10, 2013.

[13] S. Vaisey and A. Miles, "Tools from moral psychology for measuring personal moral culture," Theory Soc., vol. 43, no. 3, pp. 311-332, 2014.

[14] W. J. Wilhelm and P. Gunawong, "Cultural dimensions and moral reasoning: a comparative study,” Int. J. Sociol. Soc. Policy, vol. 36, no. 5-6, pp. 335-357, 2016.

[15] R. G. Benarrd Spka, Ralph W. Hood, Bruce Hunsberger, "The Psychology of Religion," New York: Guilford Press, 2003, p. 81.

[16] J. W. Santrock, “Adolescence,” New York: McGraw Hill, 2008, p. 242.

[17] N. E. G. M.David Miller, Robert Linn, "Measurument and Assessment in Teaching," New Jersey: Pearson Education, 2009, p. 347.

[18] S. Hari Wijayanto, "Structural Equation Modeling dengan Lisrel 8.8," Yogyakarta: Graha Ilmu, 2008, p. 138.

[19] B. J. B. R. E. A. Joseph F.Hair Jr, William C Black, "Multivariate Data Analysis," London: Pearson Education, 2014, p. 115.

[20] R. B. Kline, "Principles and Practice of Structural Equation Modeling," vol. 77, no. 27, New York: Guilford Press, 2011, p. 70. 